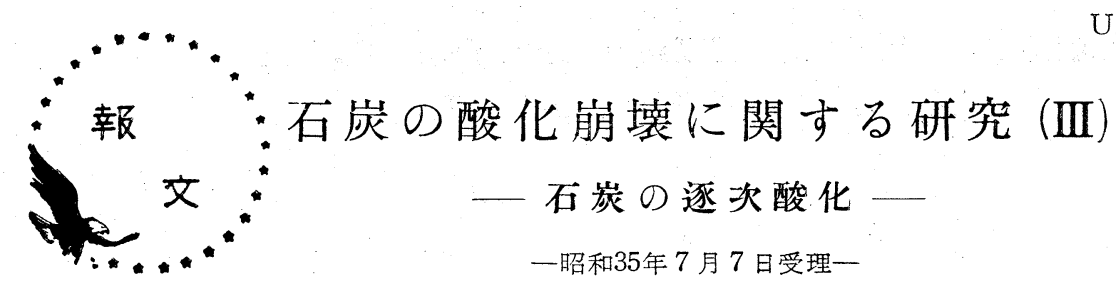

U.D.C. 662.66 .094 .3

一昭和 35 年 7 月 7 日受理一

$\begin{array}{rllll}\text { 京都大学工学部 横 川 漞 雄 渡 部良久 } \\ \text { 梶 山 } & \text { 茂武上善 信 }\end{array}$

要旨: 一石炭を $1 \mathrm{NHNO}_{3}$ の沸点で酸化すると, 比較的水素に富んだ構造の部分が崩壊して高収 率で再生フミン酸が得られるが，この選択的な反応に際してはシュウ酸执よび揮発性酸がほそんぞ 生成しない。この特徵に注目して,この際に崩壊する部分の構造を明らかにするため, 各種構造の 化合物約 30 種を $1 \mathrm{NHNO}_{3}$ の沸点で酸化し, 上述の特徴に合致するものを追求した。その結果, $\mathrm{OH}$ 基などの存在によつて酸化され易くなつている脂環族構造のものを考えるのが妥当であると結 論された。

一方，再生フミン酸および約 20 種のモデル化合物を常温のフルカリ性 $\mathrm{KMnO}_{4}$ で酸化し，化 学量論ならびに反応速度の比較によつて反応の特徴を検討した。反応初期には縮合環フェノールが ある程度選択的に酸化されると思われたが，続いて生起する反応は上の場合に較べて著しく非選択， 的であり, 再生フミン酸が水溶性のベンゼンカルボン酸類をで酸化崩壊する過程に中間的な段階を 設忷て考える必要を認めなかつた。

以上のことから，石崖分子は本質的に異なる 2 つ構造部分からなると考えられ，その一方は $1 \mathrm{NHNO}_{3}$ の沸点で酸化され崩壞する脂環族構造の部分であり，他方は芳香族性の骨骼構造をるつ 部分であると結論された。しかして,このような化学構造上の不均一性は, 覀炭より高度擵青炭に 至る間石炭化の進行につれて明確の度を加えるものである。

\section{I 。緒論}

石炭は酸化反応の条件に従つて, ある程度階段的に 酸化され崩壊することが知られている。たとえば， W. Francis ${ }^{1)}$ はこの状況を 5 段階に区別して説明し ているが, 従来の研究によると, この 5 段階の内で, その際に生起する反応が比較的選択的であると考えら れるのは, 石炭から再生フミン酸が生成する段階（酸 化第II段階と呼ぶことにする*) である。

著者ら2) 岒さき，C71.4 87.4\% の6 種の石炭を $1 \mathrm{NHNO}_{3}$ の沸点で酸化して, この条件で再生フミン 酸がきわめて高収率で得られることを示し, 酸化第而 段階が選択的に生起しているものと考えた。一方生成 する再生フミン酸の化学的性質に関しても考察を行な い，示性式を導いてその化学構造に論及した ${ }^{3)}$ 。本報 に预いては逐次酸化の各段階で崩壊する部分の化学構 造上の特質を明らかにして, 石炭の化学構造に関する

*) W. Francis ${ }^{1)}$ ( I 段階としている。
知見を深めようとするものである。

\section{II. 逐次酸化の各段階の特徵}

石炭から高収率で再生フミン酸を得る酸化方法とし ては，150 200 ${ }^{\circ} \mathrm{C}$ 附近で行なら空気または酸素によ る酸化と硝酸による酸化がよく用いられている。徒来 の研究では, これらの条件では, 再生フミン酸のそ礼 以上の酸化が進行し難いことが報じられているが，二 の段階で石炭のどのような部分が崩壊するか上いう問 題にはごく最近まで注意が向けられていなかつたよう である。しかし，原料石炭と生成する再生フミン酸と の $\mathrm{H} / \mathrm{C}$ (原子数の比) を比較すると, この段階では比 較的水素に富んだ構造の部分が崩壊することは明らか であり, B. K. Mazumdar, K. S. Anand, S. N. Roy, A. Lahiri $5^{4)}$ 泬空気酸化の研究においてこのことを 指摘している。著者らが行なつた実験結果2)の要点を 示すと第 1 表のとおりであつて, 表の最終列に示した 酸化崩壊部分の $\mathrm{H} / \mathrm{C}$ の值は原炭のそれよりも大きい 值であり, 石炭化度の高い石炭については 2 前後の值 


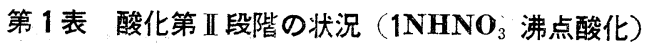

\begin{tabular}{|c|c|c|c|c|c|c|c|c|c|c|c|c|}
\hline & 試 & & 炭 & & 酸化 & & 岸 & 素 & 分 & 布 & \%) & \\
\hline \multirow{2}{*}{ 銘 } & & \multirow{2}{*}{ 唡 } & \multirow{2}{*}{$\begin{array}{l}\text { C \% } \\
\text { (daf) }\end{array}$} & \multirow{2}{*}{$\begin{array}{l}\mathrm{H} / \mathrm{C} \\
\text { 原子 } \\
\text { 数比 }\end{array}$} & \multirow{2}{*}{$\begin{array}{l}\text { 時間 } \\
(\mathrm{hr})\end{array}$} & \multirow{2}{*}{$\begin{array}{l}\text { 再生 } \\
\text { フ } \\
\text { ン酸 }\end{array}$} & \multirow{2}{*}{$\mathrm{CO}_{2}$} & $\dot{*}$ & 揮発 & 不揮発 & 残洫 & \multirow{2}{*}{$\left.\mathrm{H} / \mathrm{C}^{*}\right)$} \\
\hline & & & & & & & & ウ酸 & 性酸 & 性. 酸 & 炭 & \\
\hline 沖 & ノ & 山 & 71.4 & 0.98 & 1 & 74.1 & 12.6 & 1.2 & 2.8 & 1.6 & 7.7 & 1.2 \\
\hline 中 & & 郷。 & 72.0 & 0.95 & 1 & 42.2 & 13.8 & 2.6 & 3.7 & 14.1 & 23.6 & 1.1 \\
\hline 高 & & 松 & 77.9 & 0.89 & 3 & 78.3 & 12.9 & 1.0 & 3.0 & - & 6.7 & 1.3 \\
\hline 大 & , & 浦 & 81.5 & 0.87 & 5 & 77.6 & 7.3 & 0 & 0 & 3.9 & 11.2 & 2.1 \\
\hline 大 & & 島 & 83.6 & 0.83 & 15 & 80.6 & 10.7 & 0 & 4.3 & - & 8.8 & 1.9 \\
\hline 鹿 & & 町 & 87.4 & 0.67 & 72 & 77.3 & 11.7 & 0 & 0 & 3.5 & 7.5 & 1.3 \\
\hline
\end{tabular}

*) 再生フミン酸掞よび残㴡炭以外のものに崩壊した部分の炭素, 水素の原子数の比。

\section{である。}

また，第 1 表で特に注目されることは，石炭の酸化 第II段階ではシニウ酸および揮発性酸がほとんど生成 しないことである。この傾向は原料石炭の石炭化度が 高くなるほど著しくなる。このような特徴は著者らが 初めて指摘することであつて, 後述するように石炭の 化学構造を論じる上にきわめて重要な実験事実である と考えられる。

石炭をさらに強力な条件, たとえばアルカリ性 KM $\mathrm{nO}_{4}$ で酸化すると多量のシニウ酸および揮発性酸が 生成寸ることは周知のことであるが, 著者らは石炭を 階段的に酸化崩壊させる際の各段階における反応の特 徴を明らかにするために酸化第II段階で得られた再生

\section{第 1 図 再生フミン酸のアルカリ性 $\mathrm{KMnO}_{4}$ による酸化}

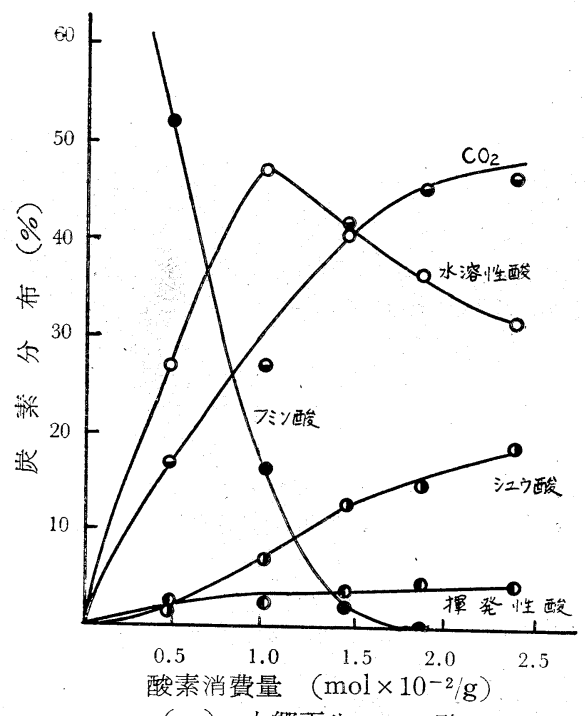

(a) 中鄉再生フミン酸
フミミン酸をアルカリ性 $\mathrm{KMnO}_{4}$ で酸化し，この際（酸 化第正段階と呼ぶ）の反応状況を検討した。

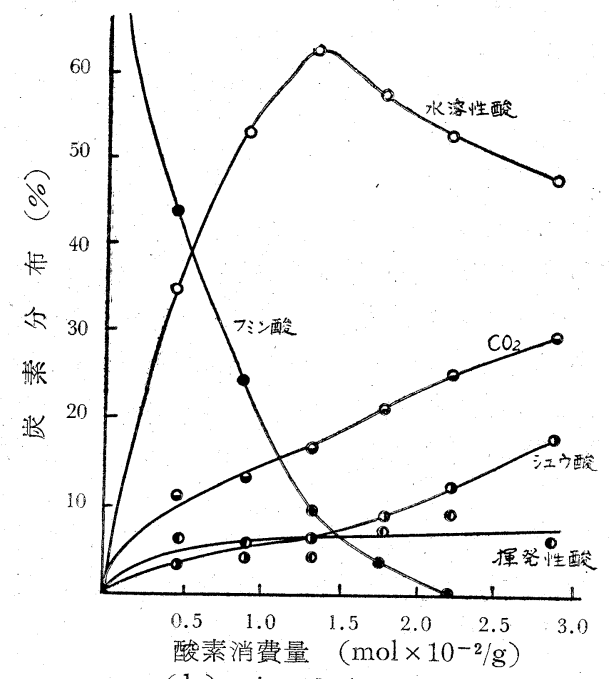

(b) 大ノ浦再生フミン酸

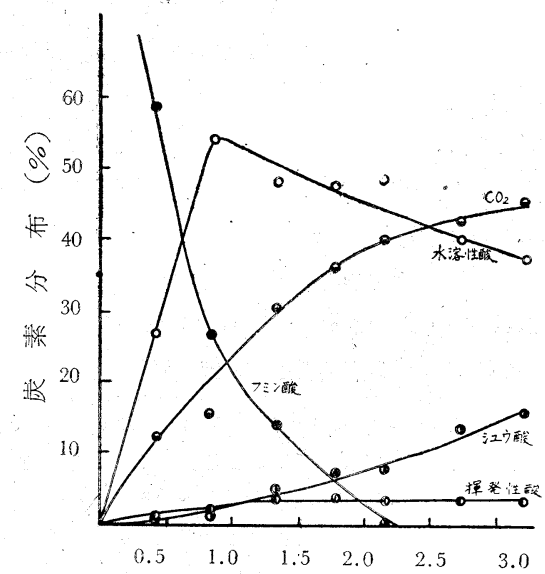

酸素消費量 $\left(\mathrm{mol} \times 10^{-2} / \mathrm{g}\right)$

(c) 鹿町再生フミン酸 
試料再生フミン酸は中郷炭を $1 \mathrm{hr}$, 大八浦炭を $5 \mathrm{hr}$, 鹿町炭を $48 \mathrm{hr} 1 \mathrm{NHNO}_{3}$ の沸点で酸化して得たもの で，その元素組成は既報2のとおりである。これらの ものは $1 \mathrm{NHNO}_{3}$ の沸点酸化に対しては比較的安定で あるが，アルカリ性 $\mathrm{KMnO}_{4}$ により常温で容易に酸化 される。

第1図 $\mathrm{a}, \mathrm{b}$ およびc よび鹿町炭の再生フミン酸を酸化した場合の酸素消費 量と生成物の量との関係を炭素収支で示したものであ る。

再生フミン酸のアルカリ水溶液に約 $1.25 \mathrm{~N}$ の $\mathrm{KMn}$ $\mathrm{O}_{4}$ を滴下すると, 試料フミン酸の種類によつて若干 異なるが $25^{\circ} \mathrm{C}$ に扔いて $0.3 \sim 0.6 \times 10^{-2} \mathrm{~mol}$ 酸素 $/ \mathrm{g}$ フミン酸に相当する $\mathrm{KMnO}_{4}$ 淔ちに消費されて脱 色さ机る。しかし，この量を越すと $\mathrm{KMnO}_{4}$ の消費さ れる速度は著しく小となる*。

第 1 図によると，いずれの場合にも反応初期には再 生フミン酸の崩壊が主として起つていると判断され， これ以後においては水可溶の高分子酸 (水溶性酸と略 称する）がさらに崩壊することが示されている。した がつて, 再生フミン酸と水溶性酸が共存する場合には 再生フミン酸がある程度選択的に酸化されると判断さ れるが, この場合同一条件で水溶性酸の崩壊 (酸化第 IV段階乙呼ぶ）も引き続いて生起するから，第段階 と第呩階は，第正段階と第段階ほど明確には区別 乙難い。

生成物を詳細にみると, 第且段階では $\mathrm{CO}_{2}$, シュ ウ酸の他に揮発性酸が生成するが, 第四段階では新し く揮発性酸の生成はないよらに思われる。しかしこの 差異は決定的なものではないし, $\mathrm{CO}_{2}$ とシュウ酸は

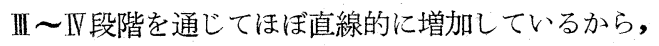
第III第IV段階で崩壊する構造は本質的に同系統のも のであると判断される**)。

以上のように，吕炭の逐次酸化崩壊の状況から判断 して，石炭は本質的に異る二つの構造部分からなり立 つており, 第段階での崩壊部分は $\left(\mathrm{CH}_{2}\right)_{n}(\mathrm{C}, \mathrm{H}$ の みに着目して)に近い構造であると考えられる。

\section{II . $1 \mathrm{NHNO}_{3}$ の沸点酸化で崩壊する構造}

石炭の酸化第 II 段階で崩壊する部分の化学構造とし

*) $\mathrm{KMnO}_{4}$ の紫色あるいは $\mathrm{K}_{2} \mathrm{MnO}_{4}$ の緑色が消失 し褐色沈搌ができるまで反応させる。 $\mathrm{KMnO}_{4}$ の量が 大となると， $\mathrm{KMnO}_{4}$ の消費される速度が著しく小と なるので，50 Cで反応を完結させた。この実験では $\mathrm{KMnO}_{4}$ の消費速度については定性的なことしかいえ ないが，反応初期に速度が大きいことは第 3 項第 3 図 に明らかに示されている。
ては, $1 \mathrm{NHNO}_{3}$ の沸点酸化で崩壊し，第 1 項に述べ たような特徴を示すような物質の化学構造が注目され るが, 従来の報文中にはこのような考察資料を求める ことはできない。著者らは第 2 表に示したモデル物質 を $1 \mathrm{NHNO}_{3}$ の沸点で $5 \mathrm{hr}$ 処理し, その際の生成物 を分析して前項に示した特徴に合致する構造を追求し た。

本項の研究の目的上, $\mathrm{CO}_{2}$ とシニウ酸の生成量に着 目して実験を行ない，それぞれの生成量を炭素収支で 第 2 表に示した。なお，反応の概況を示すために若干 の観察事項を定性的に記載した。

第 2 表によると, 単環フェノール類のベンゼン核は 容易に崩壊し, 多量の $\mathrm{CO}_{2}$ とシニウ酸を与える（実 験番号 1〜6,8,18,27,28)。しかし, 同時に生成する二 トロ化物は安定であつてレゾルシン（実験番号 7)の ように特にニトロ化を受け易い構造のものはほとんど 崩壊しない。これに反してカテコールおよび八イドロ キノン（実験番号 6,8）はきわめて酸化され易いが, これらはいずれも - $\mathrm{OH}$ 基によつて核が不安定になる ためであると考えられ，フェノール類が酸化崩壊する のはおそらく-OH 基の存在する部分で開環し, 共役 二重結合采を含む不安定な中間体を経るむのと思われ る。このような機構を考えるならば,フェノール核よ り比較的多量のシニウ酸が生成することが首肯でき る。

これに対して $-\mathrm{OH}$ 基をメチル化して $-\mathrm{OCH}_{3}$ 基に すると,アニソールおよび 1,3- ジメトオキシベンゼ ン（実験番号 9,10 )にみられるよらに, ほとんど酸化 されなくなる。

ナフトール類（実験番号 23,24）は酸化されるが, この際生成する $\mathrm{CO}_{2}$ は比較的少なくことにシニウ 酸はほとんど生成しない。このような構造では, $-\mathrm{OH}$

**) 石炭をアルカリ性 $\mathrm{KMnO}_{4}$ あるいは $\mathrm{H}_{2} \mathrm{O}_{2}$ のよ らな試薬で, 試薬の量を制限して酸化すると, 酸化第 II 段階がある程度選択的に行なわれることが W. A. Bone らの実験5で示されている。 また S. A. Ward ら6)は再生フミン酸を同梯に制限された量の $\mathrm{KMnO}_{4}$ で酸化すると, 酸化第段階と第IV段階とを区別でき るとし, 酸化第段階の産物をSub-humic acid と呼 んだ。このような中間段階のあることは第 1 図からも 想像されるのであるが, 第 II 段階と第吕段階とが区別 される場合とは明らかに程度が異なつている。なお， S. A. Ward らの Sub-humic acid に関する実験結果 に酸化第正段階を特に区別できるよ5な特徽は見当ら ない。すなわち，石炭分子は構造的に Heterogeneous であるが,再生フミン酸の構造はむしろHomogeneous であると考光た方が大局的にみて妥当である。 
第 2 表 モデル物诈の $1 \mathrm{NHNO}_{3}$ 沸点酸化（試料 $1.5 \mathrm{~g}, 1 \mathrm{NHNO}_{3} 300 \mathrm{cc}, 5 \mathrm{hrs}$ )

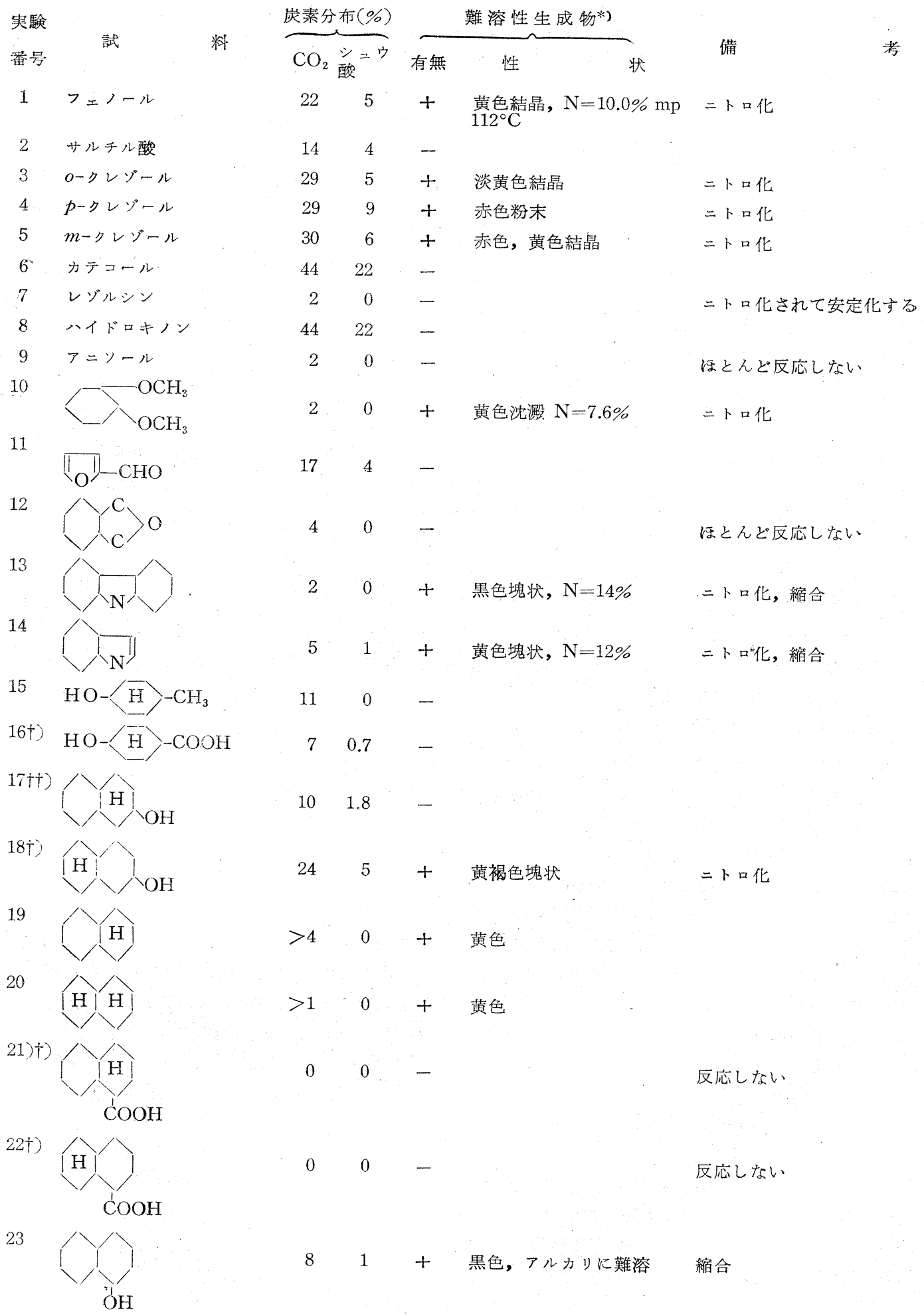


（第 2 表 続 き）

実駼
番号

基のついたベンゼン核は活性化されて酸化により開環 するが，一方の核が残つているために縮合して樹脂状 物質を生じ分解生成物を与えることが少なかつたもの と思われる。このような現象ならびに考察は，アルカ り性 $\mathrm{K} \mathrm{MnO}_{4}$ による酸化の状況（第 2 図参照）より一 層明らかである。単環フェノール誘導体と考えられる 5,6,7,8-テトラヒドロナフトール-2（実験番号18）で はこの傾向はみられない。この場合ニトロ化されて安 定化すると同時に一方で非選択的に崩壊し多量の $\mathrm{CO}_{2}$ とシュウ酸を与える。

フラン核は崩壊するとベンゼン核と同様に多量のシ 二ウ酸を与えるが（実験番号 11）, これの崩填過程も フェノールの場合と同様に考えることができる。これ そ反して，フタラン（実験番号12）のような複素環型 エーテル結合は $1 \mathrm{NHNO}_{3}$ の沸点酸化に対して安定で ある。またカルバゾールやインドール（実験番号 13， 14）ほ酸化され難く，ニト口化，縮合などの反応によ つてアルカリ不溶の黒色物質を多量に与える。
テトラリンおよびデカリン（実験番号 19,20 ) 注酸 化され難い。この 2 者はいずれす $1 \mathrm{NHNO}_{3}$ に不溶で あるから疑問が残るが, $1 \mathrm{NHNO}_{3}$ に可溶な $1,2,3,4$, 一および 5,6,7,8-テトラヒドロナフタリンカルボン酸 -1 (実験番号 21,22) や $\beta$-シクロヘキシルプロピオ ン酸（実験番号29）も同様に酸化されないから，二れ らのような脂環族構造は $\mathrm{NHNO}_{3}$ の沸点酸化に対し て安定であるように思われる。しかし4-メチルシクロ ヘキサノールや 4-オキシシクロヘキサンカルボン酸 （実験番号15,16）は比較的酸化され易い。すなわち， -OH 基が存在すると脂環族む酸化され易くなつてい る。しかもこの場合には比較的多量の $\mathrm{CO}_{2}$ が生成す るが,シニウ酸の生成はきわめて少ない。この傾向は 1,2,3,4- テトラヒドロナフトール-2 やショ糖（実験 番号 17,30$)$ にもみられる。セルロースは比較的酸化 され難い。以上のことはさきに指摘した酸化第I段階 の特徵に合致するもので, 本論文において石炭の酸化 第段階で崩壊する構造のモデルとして脂環族構造孛 
第 2 図 モデル物質のアルカリ性 $\mathrm{KMnO}_{4}$ による酸化

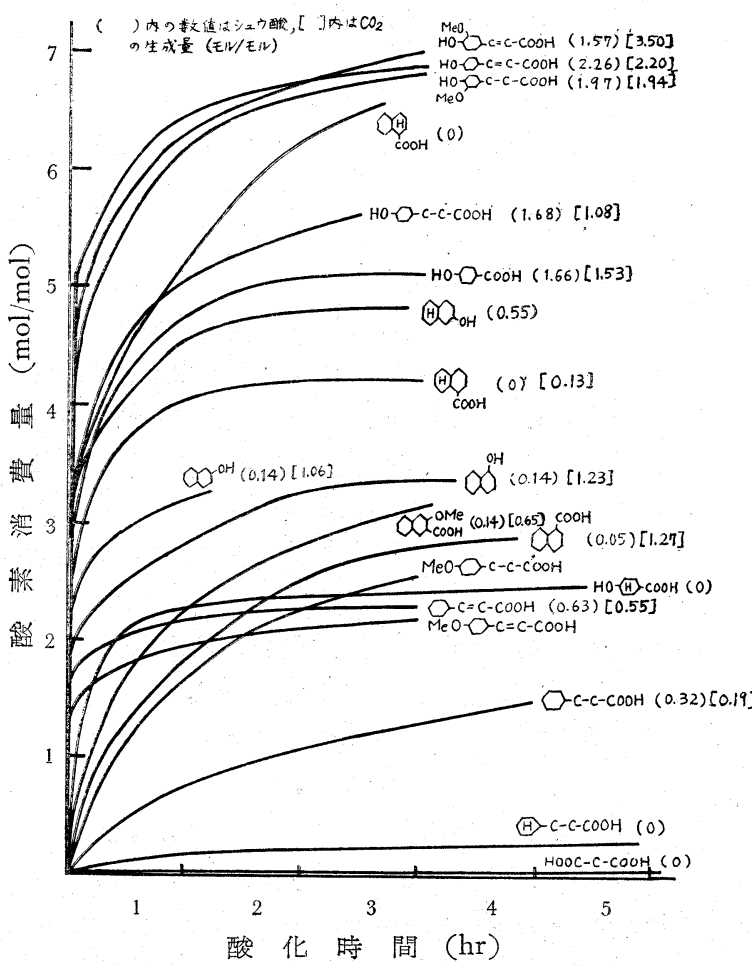

採用する論拠の1つとなるものであるが，詳細は考察 の項で論じることにする。

なふ $\mathrm{C}_{3}$ 側鎖を有する桂皮酸誘導体についてみると 実験番号 25〜29 が示すように，ベンゼン核が安定で ある限りきわめて酸化され難い。すなわち，側鎖はそ れが $\mathrm{C}=\mathrm{C}$ の二重結合を含んでいるものでさえ $1 \mathrm{NH}$ $\mathrm{NO}_{3}$ 沸点酸化に詨しては安定である。

リグニン, 亜炭フミン酸およびそれらのメチル化誘 導体（フェノール性 $\mathrm{OH}$ 基をメチル化したもの）を 同しく $1 \mathrm{NHNO}_{3}$ の沸点で $5 \mathrm{hr}$ 酸化すると, 実験番号 32〜35 にみられるように,フェノール性 $\mathrm{OH}$ 基をも つたままのものは容易に酸化され $\mathrm{CO}_{2}$, シュウ酸およ び水溶性酸を多量に与えるが，これらのメチル化物は いずれの場合にも比較的多量の再生フミン酸（酸に不 溶，アルカリ可溶の物質）を与え，単環フェノールお よびアニソールについて得た結論と一致する結果を示 している。しかし，メチル化リグニンおよびメチル化 亜炭フミン酸を酸化した場合のメトオキシル基の分布 状況は表に示したと抢りで,メチル化された核が全部 再生フミン酸として残るわけではない。これは，リグ ニン,フミン酸ともに完全にメチル化され難くなお相
第 3 図 リグニン, フミン酸類のアルカリ性 $\mathrm{KMnO}_{4}$ による酸化

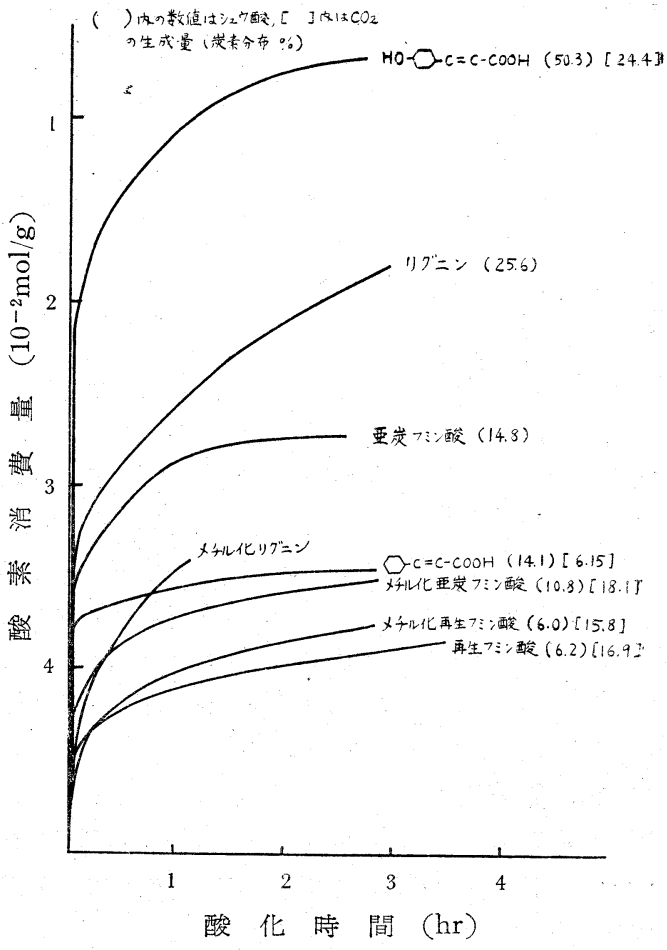

当量のフェノール核を持つており，また別に酸化を受 け易、部分もあるわけであるから，これらの部分の崩 壊によつてアニソール核を含む部分が小分子化し，水 溶性酸となるためであると解釈される。なお, 亜炭フ ミン酸の酸化崩壞に関しては異説7)があるので次項に おいてさらに検討する。

これを要するに，フェノール核*)とある種の（たと えば - OH 基をもつた）脂環族構造とが, $1 \mathrm{NHNO}_{3}$ の沸点酸化で崩壊するが, この際のシュウ酸の生成量 に注目すると，石炭の酸化第II段階に崩壊する部分の モデルとしては後者が最す適当であると結論される。

\section{III.シュウ酸を与える構造}

前項においては，石炭が酸化第II段階でシニウ酸の 生成を伴なわないで崩壊する特徴に注目して論じてき たが,このシュウ酸は周知のよらに石炭の酸化第 IV段階では多量に生成するものである。P.B.Randalt, D. M. Benger, G. M. Groocock ら ${ }^{10}$ 㤌多くのモデ ル物質をアルカリ性 $\mathrm{KMnO}_{4}$ で酸化し，この際にシ 二ウ酸を与える構造を考察しているが, 同氏らの酸化

*) G. R. Yohe $5^{\left.8)^{9}\right)}$ は石炭の初期酸化はフェノー ル性 $\mathrm{OH}$ 基をるつ部分に起ると説明している。 
条件は比較的強烈でありまた酸化の難易（反応速度） についての考察がなく著者らの目的である石炭の逐次 酸化の反応状況を考察するのに十分でないので, 若干 の実験を行なつた。

すなわち，第 2 および第 3 図に示した化合物をアル カリ性 $\mathrm{KMnO}_{4}$ によつて常温で酸化し，酸素消費量と シュウ酸生成量とから反応を化学量論的に考察し, あ わせてこれらの化合物の酸化の難易を比較して, 酸化

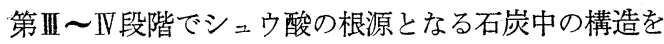
推論した。

P. B. Randalt ら $\left.{ }^{10}\right)$ の実験および本報第 2 項の実験 によつて、シュウ酸を与える構造としてはフェノール 核， $\mathrm{C}_{3}$ 側鎖ならびに縮合環構造が考えられるので, これらを代表するものとして第 2 および第 3 図に示し た試料を選んだ。図において，各試料の構造式の後に （）㧍よび[ ]で示されている数值は, 各曲線の終 点におけるシュウ酸ならびに $\mathrm{CO}_{2}$ の生成量であつて 第 2 図にあつては試料に対するモル比, 第 3 図では炭 素收支\%で示してある。なお，これらの化合物は一部 の例外を除いていずれも酸性基を持つているので反応 は均一系反応であり, また $\mathrm{KMnO}_{4}$ は常に過剩に存在 するから各曲線の傾向から反応速度を比較することが できる。

第 2 図に示されている曲線の傾斜, 酸素消費量なら びにシニウ酸の生成量について考察すると次のことが わかる。すなわち, 単環フェノールはきわめて容易に 酸化されて崩壊し，ほぼ 1 モルのシュウ酸を与えるが フェノール性 $\mathrm{OH}$ 基をむたないベンゼン核は安定で あつてこのような酸化条件では崩壊しない*)。縮合環 構造になるとナフタリンカルボン酸にみられるように 比較的容易に酸化されるが，この場合にはシニウ酸が ほとんど生成しない。同じ縮合環構造でもナフトール 類はきわめて速かに酸化され相当量のシュウ酸を与え

*) $\mathrm{MeO}-\phi-\mathrm{C}-\mathrm{C}-\mathrm{COOH}, \phi-\mathrm{C}-\mathrm{C}-\mathrm{COOH}, \mathrm{MeO}-$ $\phi-\mathrm{C}=\mathrm{C}-\mathrm{COOH}, \phi-\mathrm{C}=\mathrm{C}-\mathrm{COOH}$ 上りは $\mathrm{MeO}-\phi-$ $\mathrm{COOH}$ または $\phi-\mathrm{COOH}$ が得られた。

**) 化学量論的には次の反応が最も妥当である。

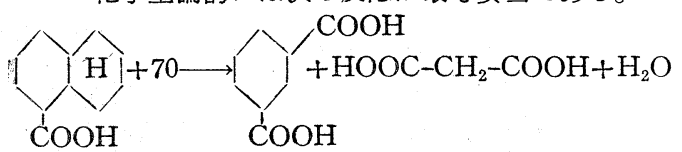<smiles>O=C(O)OC(=O)C1CCN([Ga]N2CC3CCCC(C(=O)O)C32)C1</smiles>

な抒，マロン酸は第 3 図に示すように常温のアルカ 》性 $\mathrm{KMnO}_{4}$ では殆んぞ酸化されない。
る。また2ーメトオキシナフタリンカルボン酸-3にみら れるように，ナフトールのーOH基をメチル化すると， ナフトールよりは酸化され難くなるがナフタリンカル ボン酸よりは速かに酸化され相当量のシュウ酸を与え る。

脂環族構造はアルカリ性 $\mathrm{KMnO}_{4}$ によつて容易に酸 化され多量の酸素を消費するが、シニウ酸を与えな (***)。

一方， $\mathrm{C}_{3}$ 側鎖を有する各化合物をみると，母核が 安定である場合（桂皮酸，4-メトオキシ䅅皮酸，4-メ トオキシヒドロ桂皮酸）には $\mathrm{C}_{3}$ 側鎖が選択的に開裂 してほぼ当量のシニウ酸を与える。またこの際 $\mathrm{C}=\mathrm{C}$ 2 重結合を有する側鎖の酸化速度は側鎖のそれより明 らかに大であるがシニウ酸の生成量をみると前者の 方が反応の選択性が悪い。母核にメトオキシル基が付 くと，4-メトオキシヒドロ桂皮酸と桂皮酸との比較で わかるように，アルキル側鎖の選択的切断反応の速度 が大になる。この理由は明らかでないが，さきに2-メ トオキシナフタリンカルボン酸-3とナフタリンカルボ ン酸の対比でもみられたように，メトオキシル基が酸 化崩壊を促進しているものと思われる。また, $\boldsymbol{\gamma}$-シク ロヘキシルプロピオン酸はきわめて酸化され難いから 側鎖の速かな崩壊は芳香族核の影響によるものと判断 される。母核が単環フェノールである場合には母核の 崩壊も併発するのでほぼ 2 モルのニウ酸が生成す る。

第 3 図をみると, 再生フミン酸（大ノ浦炭より得た もの）はアルカリ性 $\mathrm{KMnO}_{4}$ によつて容易に酸化され るが，この場合反応初期に急速な酸素の吸収がみられ る。この急速に消費される酸素量注図から約 $0.5 \times 10$ ${ }^{-2} \mathrm{~mol} / \mathrm{g}$ 再生フミン酸であつて, この数值は第 1 項で 定性的败察した所見と一致する。一方，大八浦再生 フミン酸に例をとるとそのフェノール性 $\mathrm{OH}$ 基の当量 は 862 と計算されるが3), 縮合フェノールが $3.5 \mathrm{~mol}$ の酸素を消費して開環崩壊しシュウ酸を与えると考え ると*)，大ノ浦再生フミン酸のフェノール性 $\mathrm{OH}$ 基を 持つ核が酸化崩壊するには $0.41 \times 10^{-2} \mathrm{~mol} / \mathrm{g}$ の酸素が 必要であると計算される。この両者の一敨はほぼ满足

*)たとえば次のように考学る。すなおち，<smiles>CC1CC(C(=O)O)C(C(=O)O)C1C=C=CC1CC(C2CCC3CCCC(O)C3C2)CC1C(=O)O</smiles> 
すべきものであって，再生フミン酸がアルカリ性 $\mathrm{KM}$ $\mathrm{nO}_{4}$ によつて酸化される際の初期反応はフェノール性 $\mathrm{OH}$ 基の存在する部位におこると考えることができ る。また, シュウ酸生成量について考察すると, 第 1 図において酸素消費量 $0.44 \times 10^{-2} \mathrm{~mol} / \mathrm{g}$ の場合のシ二 ウ酸生成量は炭素收支で $3.5 \%$ であり，一方大ノ浦フ ミン酸 (C65.5\%，フェノール性 $\mathrm{OH}$ 当量 862 ) が上 述の反応によつて崩壊すると仮定して計算したシュウ 酸生成量注 $4.2 \%$ であつて良好な一致がみられる。こ のような数值の一致は中郷再生フミン酸および鹿町再 生フミン酸においても同程度に認められるが, モデル 実験におけるナフトールおよび2ーメトオキシナフタリ ンカルボン酸-3がシュウ酸の生成量に関しては上述の 量論に程遠い結果を示しているので，上述の仮説は決 定的なものとはいえない。

以上の諸知見を総合して考えると，酸化第段階の 初期反応はフェノール性 $\mathrm{OH}$ 基が存在する部位におい て起り,この際抢そらく縮合環フェノールの開裂によ つてシュウ酸が生成するものと思われる。しかし，ア ルカリ性 $\mathrm{KMnO}_{4}$ 酸化によつては, 反応速度の大小は あつても，きわめて広範囲な構造が非選択的に崩壊す るから, 比較的速かな初期反応の後には縮合環構造の 石炭基本構造が各所で切断され，この芳香族核の崩壊 生成物として多量のシ二ウ酸が生成するものと思われ る。

リグニン，垔炭フミン酸およびそれらのメチル化誘 導体（いずれも - $\mathrm{OH}$ 基のみメチル化したもの）をア ルカリ性 $\mathrm{KMnO}_{1}$ で酸化した結果が第 3 図に示して あるが，これらのものは再生フミン酸に較べて単位重 量当りの酸素消費量が大きくがつ酸化速度も大であ る。またメチル化誘導体はいずれも酸素消費量も酸化 速度もともに小さくなり，シュウ酸の生成量も減少す る。歴青炭より得た再生フミン酸の酸素消費量, 反応 速度はこれらに比較してともに小さく，しかもフェノ 一ル性 $\mathrm{OH}$ 基をメチル化してもほとんど影響を受けな い。このようなことは前者が崩壊しやすい単環性フェ ノール核を多く有しているのに対して, 後者ではフェ ノール核の絶体量も少なくかつこのフェノール核は縮 合環構造のものが多いことを示している。これらの結 論は $1 \mathrm{NHNO}_{3}$ 沸点酸化に扮いて得られた結論と一致 するものである。

なお，縮合環フェノールをメチル化しても単環フェ ノールをメチル化した場合のように著しい勃果が生じ ないことは，2-メトオキシナフタリンカルボン酸-3を モデルとした実験で示されている。
上述の論議において著者らは再生フミン酸の構造と 対比して考えるために亜炭フミン酸についても考察し その基本構造が単環フェノール核であると考えた。亜 炭フミン酸の構造を論じるのは本論文の主題からいさ さか逸脱することになるが，本報に示した著者らの実 験結果と，硧口7)がさきに亜炭フミン酸の化学構造を 論ビた際に示している考察との間に矛盾が生じている のでここに若干の実験を加えて論じておきたいと思 う。

第 2 図の曲線の傾斜から，不飽和結合のある側鎖の 切断と単環フェノール核の崩壊速度はいずれもきわめ て大きく両者の間に殆んど差が認められないが，飽和 結合側鎖の切断反応の速度は比較的小さいことがわか る。またこの際の反応の反応次数が試料および $\mathrm{KMn}$ $\mathrm{O}_{4}$ に対してそれぞれ1次であると仮定して，大過剩 の試料が存在するような条件で求めた概略の反応速度 定数は第 3 表法したと㧍りであつて，上述の定性的 比較をより明確に示している。

\section{第 3 表 反応速度の比較}

$\begin{array}{cc}\text { 反試速度定数 } & k \\ \left(l \cdot \mathrm{mole}^{-1} \cdot \mathrm{sec}^{-1}\right)\end{array}$

桶口7) 注亜炭フミン酸をアルカリ性 $\mathrm{KMnO}_{4}$ で酸 化し, 反応初期に扔いてそのフェニルプロパンの $\mathrm{C}_{3}$ 側鎖が選択的に切断されてシュウ酸，揮発性酸ならび に $\mathrm{CO}_{2}$ を与えるとし，化学量論的関係から亜炭フミ ン酸がフェニルプロパンで代表されるような構造を持 つていることを証明できたとしている。しかし，上に 述べたように著者らのアルカリ性 $\mathrm{KMnO}_{4}$ 酸化の速度 に関する実験によると，同氏の考察には誤りがあつて この際には当然フェノール核の崩壊も併発すると考え なければならない。

亜炭フミン酸が単環フェノール核を基本構造として いるであろうことは樋口の他の研究1加らもいえるこ とであるし，著者らの $1 \mathrm{NHNO}_{3}$ 酸化の実験結果もこ の考え方を肯定するものである。また亜炭はその生成 過程に余り強力な化学変化を受けていないと想像され るから，その構造をリグニンのそれに類似を求めるこ とも妥当である。したがって，著者らも亜炭フミン酸 
の化学構造としては古くからある縮合環構造 ${ }^{12}$ よりは 単環フェノール核を含む構造を考えるのが妥当である と考えるものであり，この点においては桶口の所説を 否定するものではない。

\section{$\mathrm{V}$ ．石炭の逐次酸化で崩壊する構造}

石炭加ら再生フミン酸に至る酸化第II段階では, 比 較的水素に富んだ部分が崩壊することはすでに指摘さ れている処であるが, その具体的な構造に関しては直 接論じられていない。すなわちここような構造につ いてあるものはアルキル側鎖と考え $\left.{ }^{13)},{ }^{14}\right)$ また多くの 研究者 ${ }^{4315) ~ 199 ~}$ 法アルキル側鎖および脂環族構造と考 えているが，結局は $\left(\mathrm{CH}_{2}\right)_{n}$ の組成の構造が酸化第 II 段階で失なわれることを述へているに過ぎない。また これらの論議の資料となつている実験は，いずれも 150 200 ${ }^{\circ} \mathrm{C}$ に打汀る空気酸化であつて, この条件で は比較的選択的な反応が生起するという見解 ${ }^{19}$ もある が, 著者らの取り扱つた反応の方がさらに選択性が良 好であると思われ, またこの反応では反応過程の詳細 な追跡が可能である。

著者らは歴青炭の酸化第I段階で崩壊する部分の構 造として, 第1 項および第 2 項末尾に述べたように, 脂環族構造を考えるのが最も妥当であると考えるもの であるが*)，本項に㧈いてはこのような構造について さらに考察を加えてみよう。瀝青炭を $1 \mathrm{NHNO}_{3}$ の沸 点で酸化すると $\left(\mathrm{CH}_{2}\right)_{n}$ に近い組成の部分 $(\mathrm{C}$ と $\mathrm{H}$ のみ着目して) がきかめて選択的に, しかもシ二ウ酸 の生成を伴なわないで崩壊する特徵があるが，アルコ 一ル性 $\mathrm{OH}$ 基をもつた脂環族構造のモデル化合物が 同じ酸化条件で同様な特徴を示すことは既に述べた。

大ノ浦炭を $1 \mathrm{NHNO}_{3}$ の沸点で酸化した際の原料石 炭中の酸素の収支を計算すると, 原料炭の酸素の約 25 \%が酸化第 II 段階で再生フミン酸以外の酸化生成物中 に失なわれたことになる。このことはこれだけの酸素 が選択的に崩壊した脂環族構造部分に結合していたこ とを意味するものであり，したがつて $\left(\mathrm{CH}_{2}\right)_{n}$ なる 組成供酸素を加えるなれば, 酸化第II段階で失なわれ

*) 酸化崩壊とは無関係に, 硫黄による脱水素反応 ${ }^{20}$ やX線回折による知見 ${ }^{21}$ 加ら石炭中に脂環族棈造が存 在すると述べた報文がある。また A. Bennig 22) は石 炭の硝酸酸化に打いて最も酸化され易いのはヒド口芳 香族構造であろうとしているが, その実験根拠は薄弱 である。

**) 再生フミン酸の官能基の酸素以外の酸素と残 渣炭の酸素がすべて原料石炭中の酸素であると考学 る。また先に提出した再生フミン酸の示性式引を用い ている。
る部分の組成は $\left(\mathrm{CH}_{2} \mathrm{O}_{0 \cdot 2}\right)_{n}$ と計算される。もつと もこの計算に当つては多くの仮定**) をおいており, また酸素含有量の数值の精度が余り高くないので, 上 述の数值に相当誤差のあるのは止むを得ない。

石炭分子中にアルコール性 $\mathrm{OH}$ 基の存在を明確に証 明した報文注見当らないが，このものの存在を考慮に 入れることは決して無理なこととは思われないし，上 述の数值はこのような仮定を許すむのであると考えら れる。しかし，これらの酸素がすべてアルコール型で あるとは考えないし，酸化第正段階で崩壊する部分が アルコール性 $\mathrm{OH}$ 基をもつた脂環族構造のものである と限定するわけでもないが，石炭中に比較的酸化され 易い状態で脂環族構造の部分が存在することは明らか である。

このような部分が崩壊することによつて, $\mathrm{COOH}$ 基を持つた再生フミン酸が生成するのであるから, 石 炭分子は, 再生フミン酸の母核に引きつがれている比 較的酸化され難い構造部分（基本構造と呼ぶことにす る）が脂環族構造を持つ部分によつて相互に結合され て組み立てられているものと考えられる。これをさら に模型的に説明するなれば，煉瓦積みの建造物を石炭 分子とみればよい。すなわち，この際個々の煉瓦は石 炭の基本構造でありその間を結び付けているセメント は脂環族構造に相当する。石炭分子中に脂環族構造を 考えた石炭の化学構造模型は W. Fuchs, A. G. Sandhoff ${ }^{23}$ や D. W. van Krevelen ${ }^{24}$ ) らによつて提出 されているが,これらは化学的実証に基づいたもので はない。また著者らの考えている構造模型とも相当異 なつたものであるがこれらの詳細については別稿に 譲る。

次に石炭分子の中で, 基本構造と結合部分 (脂環族 構造）とが占める割合を炭素原子の数の割合で示すと 第 4 表のようになる。この計算に当つては, 残渣炭は 除外して再生フミン酸になつた部分と崩壤した部分と

\section{第 4 表 基本構造の占める割合}

\begin{tabular}{|c|c|c|c|c|}
\hline 試 & 料 & 孷 & & $\begin{array}{l}\text { 基本構造に属する } \\
\text { 素素数 (\%)*) }\end{array}$ \\
\hline 沖 & ノ & 山 & & $77(52)$ \\
\hline 中 & & 郷 & & $53(34)$ \\
\hline 高 & & 松 & & 80 \\
\hline 大 & > & 浦 & - & 83 \\
\hline 大 & & 島 & & 84 \\
\hline 鹿 & & 町 & & 82 \\
\hline
\end{tabular}

*) 再生フミン酸の最高収率を基準としている。 （）内は安定な再生フ:ン酸の量を基準と している。（文献 2 参照） 
のみに注目することとし, 再生フミン酸の $\mathrm{COOH}$ 基 の炭素原子は本来結合部に属していたものと考えた。 表にみられるように，石炭化度が高くなるに従つて基 本構造の占める割合が大きくなる。

以上の考察は主として歴青炭に適応するものであ る。すでに指摘したように（第1表おううび前報2）参

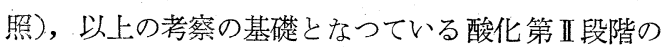
特徴は石炭化度が低くなるに従つて不明確となつてく る。すなわち, $1 \mathrm{NHNO}_{3}$ 沸点酸化の条件で $\mathrm{CO}_{2}$ な らびに低分子量の有機酸になる部分が多く,この際生 成した再生フミン酸はその収量も少なくかつこの酸化 条件汶して不安定である。

この現象ならびに低炭化度炭が多量の酸素を持つて いる事実から低炭化度炭の化学構造を考えると, 低炭 化度炭の分子にあつては, 瀝青炭にみられる構造的に 区別される二つの部分の独立的な発達が十分でないと 考光られる。しかして低炭化度炭の分子構造が酸化反 応に対して非選択的に不安定であるのは, 主として, 瀝青炭の基本構造にまで発達すべき芳香族構造の部分 が多量のフェノール性 $\mathrm{OH}$ 基を持つており，かつその 縮合度が小さいためであると考えられる。

\section{II. 実験}

A. 試料の調製およびその性状

a）再生フミン酸㧠よびその誘導体

中郷炭, 大八浦炭および鹿町炭より得たものであつ て, その調製法ならびに性状は前報》に記載した。

b ）リグニンおよびそのメチル化物

松材の鋸屑をベンゼンアルコールの等量混合物の沸 点で抽出し，これより $42 \% \mathrm{HCl}$ を用いて R. Willstäter の方法 ${ }^{25)}$ 亿従いリグニンを得た。メチル化の方 法は再生フミン酸に対するのと同じである。性状は第 5 表に示した。

\section{第 5 表 関連試料の性状}

試 料
無水無灰物基準(\%) $\mathrm{C} \overbrace{\mathrm{H}}^{\mathrm{OCH}}{ }_{3}$ $\begin{array}{lll}64.3 & 5.9 & 13.8\end{array}$ $\begin{array}{lll}66.1 & 5.5 & 20.8\end{array}$ $55.3 \quad 4.9$ $60.3 \quad 4.2$ $65.5 \quad 5.7$

*) $\mathrm{OH}$ 基のみメチル化されている。

c）亜炭, 亜炭フミン酸およびそのメチル化物

使用した亜炭法中山炭質亜炭である。これを $2 \%$

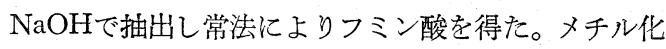

法は再生フミン酸の場合と同じである。性状は第 5 表 に示した。

d）モデル物質の合成法

モデル物質の合成法の概略と製品の融点または沸点 は次のとおりである。（）内の数值は文献值を意味 する。ここに記載されていないものは市販化学用一級 品であり, 3 種のクレン゙ールは大阪市立工業研究所渡 辺昭二博士より提供されたものである。

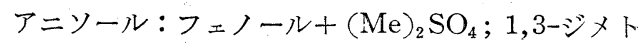
オキシベンゼン：レゾルシン+ $(\mathrm{Me})_{2} \mathrm{SO}_{4} ;$ フタラン : H. C. Howard ら ${ }^{26)}$ の記載による, bp $190^{\circ} \mathrm{C}(192)$; 4-オキシシクロヘキサンカルボン酸： $p$ ーオキシ安息香 酸を $160^{\circ} \mathrm{C}$, ラネーニッケルで水素化, エーテルより 再結晶, $\mathrm{mp} 120^{\circ} \mathrm{C}(120 \sim 121) ； 1,2,3,4$-テトラヒド ロナフトール-2 : $\beta$-ナフトールを $160^{\circ} \mathrm{C}$, ラネーニッ ケルで水素化しアルカリで洗涹, $\mathrm{Kp}_{70} 180 \sim 183^{\circ} \mathrm{C}$ $\left(\mathrm{Kp}_{54}\right.$ 176.5 178)； $\alpha$-ナフタリンカルボン酸：ナフ

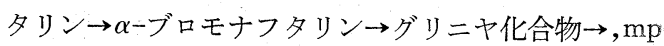
$161^{\circ} \mathrm{C}$ (162)；2-メトオキシナフタリンカルボン酸-3 :2-オキシナフタリンカルボン酸-3+ $(\mathrm{Me})_{2} \mathrm{SO}_{4}$ アル コール性 $\mathrm{KOH}$ で加水分解, アルコール上り再結晶, $\mathrm{mp} 130.5 \sim 132.0^{\circ} \mathrm{C}(133) ; 1,2,3,4-$-テラヒドロナフ タリンカルボン酸-1 : $\alpha$-ナフタリンカルボン酸を 160 ${ }^{\circ} \mathrm{C}$, ラネーニッケルで水素化, 水より再結晶, $\mathrm{mp}$ $85^{\circ} \mathrm{C}(85) ; 5,6,7,8$-テトラヒドロナフタリンカルボン 酸-1: テトラリン $\rightarrow 5,6,7,8$-テトラヒドロ-1-ブロモ ナフタリン $\rightarrow$ リ゙リニヤ化合物 $\rightarrow$, 水より再結晶, $\mathrm{mp}$ $105^{\circ} \mathrm{C}(128)$; ヒドロ桂皮酸: 桂皮酸を $70^{\circ} \mathrm{C}$, ラネー ニッケルで水素化, 水より再結晶, $\mathrm{mp} 47.8^{\circ} \mathrm{C}(47$ 48）４4-オキシ桂皮酸：p-オキシベンツアルデヒドと マロン酸よりパーキン反応による, 水より再結晶, $\mathrm{mp} 212^{\circ} \mathrm{C}(215) ; 4$-メトオキシ桂皮酸：4-オキシ桂皮 酸+ $(\mathrm{Me})_{2} \mathrm{SO}_{4}, 10 \% \mathrm{KOH}$ で加水分解, 水上り再結 晶, $\mathrm{mp} 168^{\circ} \mathrm{C}(170 \sim 185)$ ；4-オキシヒドロ桂皮酸： オキシ桂皮酸を $70^{\circ} \mathrm{C}$, ラネーニッケルで水素化, 水

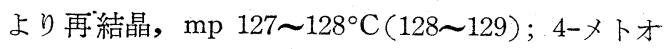
キシヒドロ桂皮酸: 4-オキシヒドロ桂皮酸 $+(\mathrm{Me})_{2}$ $\mathrm{SO}_{4}, 10 \% \mathrm{KOH}$ で加水分解, 水より再結晶, $\mathrm{mp} 101$ 〜 103ㄷ C (102 103.5)；3-メトオキシー4-オキシ桂皮 酸: バニリンとマロン酸よりパーキン反応による, 水 より再結晶, mp 169〜171(173)；3ーメトオキシ4-オキ シヒドロ桂皮酸: 3-メトオキシ4-オキシ桂皮酸を 70 ${ }^{\circ} \mathrm{C}$, ラネーニッケルで水素化, 水より再結晶, $\mathrm{mp} 89$ 〜90ㄷ $\mathrm{C}(89 \sim 90) ; \beta$-シクロヘキシルプロピオン酸： 桂皮酸を $200^{\circ} \mathrm{C}$, ラネーニッケルで水素化, 溶媒ジオ 
キサン,アマイドの $\mathrm{mp} 119 \sim 120^{\circ} \mathrm{C}(120)$, 水素化の

溶媒洔記したもの以外はすべてエーテル。

B. 再生フミン酸のアルカリ性 $\mathrm{KMnO}_{4}$ 酸化

再生フミン酸約 $450 \mathrm{mg}$ (無水試料として) を $0.25 \mathrm{~N}$ $\mathrm{NaOH} 100 \mathrm{cc}$ に溶解し, これに $1.25 \mathrm{~N}^{2} \mathrm{KMnO}_{4}$ 溶液 を $10,20,30,40,50,60$ および $70 \mathrm{cc}$ 加え常温で強くか きまぜた。20ccまでは速かに消費されたが，これ以上 になると反応が遅くなるので約 $50^{\circ} \mathrm{C}$ に加熱し， $\mathrm{KM}$ $\mathrm{nO}_{4}$ がすべて $\mathrm{MnO}_{2}$ になるまで反応させた。反応終 了後 $\mathrm{MnO}_{2}$ を汇別し, 沪液について未反応フミン酸 $\mathrm{CO}_{2}$, シニウ酸および揮発性酸を定量した。すなわち 沪液の一部から $\mathrm{HCl}$ で沈搌するフミン酸を $\mathrm{KOH}$ に 溶解し, 比色法によって定量した。 $\mathrm{CO}_{2}$ は $\mathrm{KOH}$ 溶 液に吸収させて重量法によりシシニウ酸はカルシウム 塩として沈搌させて容量法で, 揮発性酸は $\mathrm{N} / 100 \mathrm{Na}$ $\mathrm{OH}$ で滴定して求めた。炭素収支を計算する汇当つて は，末反応フミン酸は原料フミン酸と同じ組成であり また揮発性酸はすべて酢酸であると仮定し，残部を水 可溶性酸とした。

C. $1 \mathrm{NHNO}_{3}$ の沸点酸化

$1 \mathrm{NHNO}_{3} 300 \mathrm{cc}$ に試料 $1.5 \mathrm{~g}$ （例外は第2 表に記 載した）を投じ，還流冷却器を付して $5 \mathrm{hr}$ 煮拂した。 $\mathrm{CO}_{2}$ とシニウ酸を前報》に記載した方法で定量した。

D. アルカリ性 $\mathrm{KMnO}_{4}$ による酸化

試料 $0.5 \mathrm{~g}$ を $1 \mathrm{NKOH} 50 \mathrm{cc}$ 汇溶解し, I/2NKMn $\mathrm{O}_{4}$ を $200 \mathrm{cc}$ 加えて $20^{\circ} \mathrm{C}$ に保つた恒温槽につけ強く かきまぜた。3hr の間に 6 8 回それぞれ 10cc ずつ をピペットで取り出し，有効酸素を定量した。すなお ち, 反応溶液 $10 \mathrm{cc}$ を $10 \% \mathrm{KI}$ の $10 \mathrm{cc}$ に投し， $\mathrm{HCl}$ で酸性にして $\mathrm{N} / 10 \mathrm{Na}_{2} \mathrm{~S}_{2} \mathrm{O}_{3}$ で滴定した。反応が進む につれて $\mathrm{MnO}_{2}$ が生じるから反応溶液は不均一系と なるが，強くかきまぜながら滴定試料を取り出せば， $\mathrm{MnO}_{2}$ を平均に取り出せることを確かめた。 $\mathrm{KMnO}_{4}$ の消費量がほぼ一定になれば, 残つている反応液に $\mathrm{FeCl}_{2}$ あるい法 $\mathrm{FeSO}_{4}$ 溶液を加えて $\mathrm{KMnO}_{4}$ を還 元し, $\mathrm{MnO}_{2}$ と $\mathrm{Fe}(\mathrm{OH})_{3}$ を沪別した後沪液につい てシニウ酸と $\mathrm{CO}_{2}$ を既述の方法により定量した。

E。アルカリ性 $\mathrm{KMnO}_{4}$ による酸化速度の測定 試料 $0.3 \sim 0.4 \mathrm{~g}$ を $1 \mathrm{NKOH} 25 \mathrm{cc}$ に溶解し, N/100 $\mathrm{KMnO}_{4} 100 \mathrm{cc}$ を加え, Dの場合と同様にして $\mathrm{KMn}$ $\mathrm{O}_{4}$ の残量を定量し次式住従つて反応速度定数 $k$ を計 算した。

$$
-\frac{a\left[\mathrm{KMnO}_{4}\right]}{d t}=k[\text { 試料 }] \cdot\left[\mathrm{KMnO}_{4}\right]
$$

[試料 $] \gg\left[\mathrm{KMnO}_{4}\right]$ であるから， $-d\left[\mathrm{KMnO}_{4}\right] / d t=k \cdot$ const $\cdot\left[\mathrm{KMnO}_{4}\right]$

F . 元素組成掞よび官能基の定量

前報〉と同じくセミミクロ分析を行なつた。

\section{文献}

1) W. Francis, Fuel, 17, 363 (1938).

2）梶山茂，横川親雄，渡部良久，武上善信，燃協 誌, 37, 582 (1958).

3）暒山茂, 横川親雄, 渡部良久, 武上善信, ibid., 38, 86 (1959).

4) B. K. Mazumdar, K. S. Anand, S. N. Roy, A. Lahiri, Brennstoff-Chem., 38, 305 (1957).

5) W. A. Bone, L. Horton, S. G. Ward, Proc. Roy. Soc. (London), 127A, 480 (1930).

6) A.E.W. Bailey, I. M. Kimberley, L. Turnér, S. G. Ward, Fuel, 34, 37 (1955).

7）樋口耕三，然協誌，38, 374 (1959).

8) G. R. Yohe, E. O. Blodgett, J.A.C.S., 69, 2644 (1947).

9) G. R. Yohe, D. R. Hill, J. E. Dunbas, F. M. Scheidt, ibid., 75, 2688 (1953).

10) P. B. Randalt, D. M. Benger, G. M. Groocock,'Proc. Roy.Soc. (London), A 165, 432 (1938).

11）桶口耕三，燃研報告 67 号, (1952).

12) W. Fuchs, Brennstoff-Chem., 12, 266 (1931).

13) J. A. Whitaker, J. Inst. Fuel, 27, 218 (1955).

14）藤井修治，横山不二子，燃協誌，38，329（195 9).

15) O. Grosskinsky, B. Jüttner, BrennstoffChem., 39, 5 7, (1958).

16) C. Kröger, H. Bürger, ibid., 40, 76 (1959).

17) S. K. Chakarabartty, B. K. Mazumdar, A. Lahiri, Fuel, 37, 498 (1958).

18) O. Grosskineky, G. Huck, W. Lange, Brennstoff-Chem., 40, 252 (1959).

19) B. K. Mazumdar, A. Lahiri, Fuel, 37, 495 (1958).

20) B. K. Mazumdar, S. K. Chakarabartty, A. Lahiri, Fuel, 38, 112 (1959).

21) S. Ergun, V. H. Tiensun, Nature, 183, 1668 (1959).

22) A. Bennig, Brennstoff-Chem., 36, 120 (1955).

23) W. Fuchs, A. G. Sandhoff, Ind. Eng. Chem., 34, 567 (1942).

24) D. W. van Krevelen, Brennstoff-Chem., 35, 289 (1954).

25) R. Willstätter, L. Kalb, Ber,. 55, 2637 (1922).

26) C. H. Ruof, J. Entel, H. C. Howard, J.A. C.S., 74, 3440 (1952). 


\title{
Studies on the Oxidative Degradation of Coal (III)
}

\author{
Stepwise Oxidative Degradation of Coa1 \\ by Chikao Yokokawa, Yoshihisa Watanabe, Shigeru Kajiyama \\ \& Yoshinobu Takegami \\ (Faculty of Engineerig, Kyoto University)
}

\begin{abstract}
SYNOPSIS :- When coals are oxidized by boiling with $1 \mathrm{NHNO}_{3}$, comparatively hydrogen rich part in coal molecule is destroyed producing the humic acid in good yield, and in this selective oxidation process a distinctive feature that oxalic acid and volatile acids are scarecely produced is noticeable. Regarding to this speciality, for the purpose to discuss the structural aspects of the part which is destroyed in this process, about thirty various structural compounds were boiled in $1 \mathrm{NHNO}_{3}$, and the compounds whose chemical behaviours fit for the above-mentioned speciality were searched. Alicyclic structure seemed most suitable.
\end{abstract}

On the other hand, humic acids prepared from bituminous coals by boiling in $1 \mathrm{NHNO}_{3}$ and about twenty substances were oxidized with alkaline permanganate at $20^{\circ} \mathrm{C}$. According to the considerations aloubt chemical stoichiometry and reaction rate, no special facts indicating the selectiveness of this process were observed, excepting that at the early stage of reaction the condensed phenolic structure seemd to be oxidized; comparatively selectively; and it was followed by the conclusion that there is no reason to consider some intermediate steps in the degradation process of humic acid to benzene carboxylic acids.

After all, it was concluded that the molecule of coal consists of two distinctive structural parts; one is destroyed by boiling with $1 \mathrm{NHNO}_{3}$ and is in alicyclic structure, the other is resist for $1 \mathrm{NHNO}_{3}$ at its boiling point and is in condensed aromatic structure. This heterogenety in chemical structure of coal molecule, however, increasees its clearness according to the advance of the coalification up to the higher rank bituminous coal.

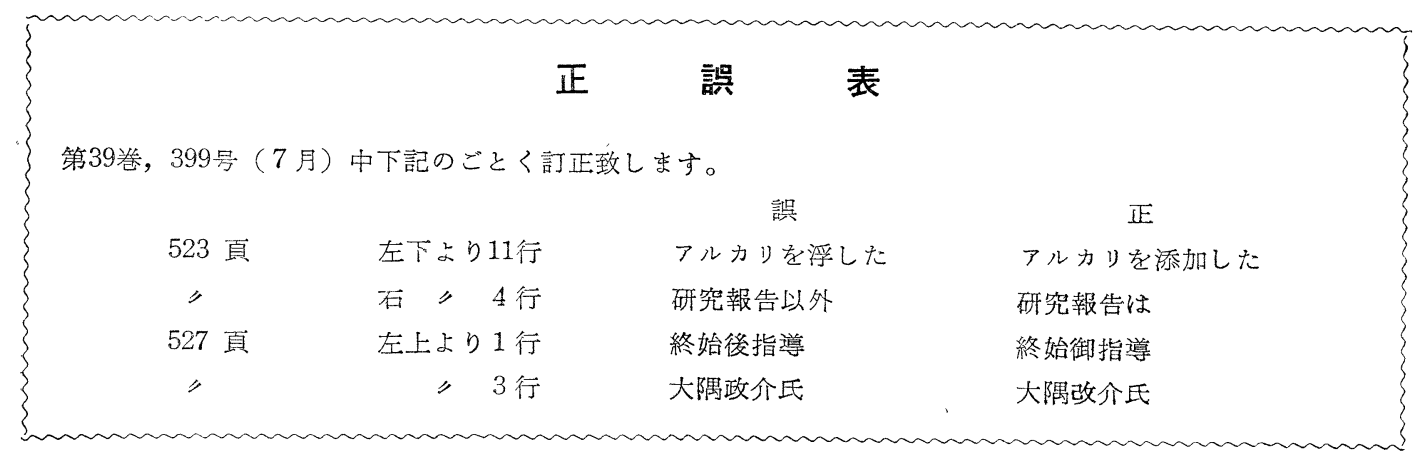

